\title{
Water Quality Index for Assessment of Potability of Groundwater Resource in Langata Sub County, Nairobi-Kenya
}

\author{
EA Ochungo ${ }^{1, *}$, GO Ouma ${ }^{2}$, JPO Obiero ${ }^{3}$, NA Odero ${ }^{4}$ \\ ${ }^{1}$ Institute for Climate Change and Adaptation (ICCA), University of Nairobi, Nairobi, Kenya \\ ${ }^{2}$ Department of Meteorology, University of Nairobi, Nairobi, Kenya \\ ${ }^{3}$ Schools of Engineering, University of Nairobi, Nairobi, Kenya \\ ${ }^{4}$ Department of Electrical and Electronics Engineering, Machakos University, Machakos, Kenya \\ *Corresponding author: elishakech1@gmail.com
}

Received April 11, 2019; Revised May 14, 2019; Accepted June 04, 2019

\begin{abstract}
Water Quality Index (WQI) computation method based on quality parameters' selection, assigning of weights, creation of sub-indices and calculation of the aggregated quality value has been used for many decades from the early 1960s to check on the pollution stati of watersheds. Today, due to rising water demand in the face of increased drought induced water shortage challenges and rampant pollution of the water sources, consumers augment their needs by using groundwater resources like in the case of Langata sub County in Nairobi city-Kenya. Little however, has been done to assess the overall potability of groundwater quality here. Accordingly, in the present study, a Water Quality Index (WQI) was developed by Weight Arithmetic Water Quality Index (WAWQI) method to fill that identified gap using a five categories' grading scale, viz. excellent (A), very good (B), good (C), fairly good (D), suitable (E) and unsuitable (F). To realize this, chemical parameters' concentration ranges were defined on the basis of the Kenyan Standards (KS) and International Standards of World Health Organization (WHO).Subsequently, a total of eight chemical parameters were selected based on their level of occurrence in borehole commissioning data obtained from Water Resource Management Authority's database of the area viz; K+, $\mathrm{Na}+, \mathrm{Ca} 2+, \mathrm{Fe} 2+, \mathrm{F}-, \mathrm{Cl}-, \mathrm{SO} 4-2$ and $\mathrm{Ec}(\mu \mathrm{S} / \mathrm{cm})$. Out of a total of 137 boreholes, only 39 had complete eight chemical parameters. These 39 boreholes' water quality assessment is taken in this study as a true representation of the entire area's groundwater quality. The individual concentrations were spatially plotted using Surfer Software's digital terrain model (DTM) which produced contoured maps in different chroma saturations including the overall aggregated concentration to facilitate scale ranking. The WQI for the study area is 53.18 in a scale of 1 to 100 , with one being excellent. In this case, the groundwater quality was ranked as grade ' $\mathrm{C}$ '. WQI calculation method is known to improve the understanding of water quality issues by integrating a suite of data into a single value which describes the status of water quality. WQI is very useful for the water management authorities because it facilitates their informing of the public on water quality in a simplified form.
\end{abstract}

Keywords: index, water, potability, quality

Cite This Article: EA Ochungo, GO Ouma, JPO Obiero, and NA Odero, "Water Quality Index for Assessment of Potability of Groundwater Resource in Langata Sub County, Nairobi-Kenya." American Journal of Water Resources, vol. 7, no. 2 (2019): 62-75. doi: 10.12691/ajwr-7-2-4.

\section{Introduction}

Interest to document water quality can be traced in historic writings such as the Bible where Babylon city's wastewater discharge management is explained [1]. It is a ubiquitous fact that the literature on drinking water quality is still on a spawning spree everywhere due to the rising water demand in the face of increased drought induced water shortage challenges and pollution of the few remaining drinking water sources. This is attributed to the unsubstitutable role of water in all life forms; the reason water is declared as a right to all [2]. As such, the quality of water from any given water resource's body must be known before planning for its use [3]. The old way of knowing water quality is usually by comparing the measured physico-chemical and biological parameter values with existing standard guidelines. However, this methodology is only suitable in identifying the contamination sources and meeting of legal requirements on water quality. It fails to give the much needed spatial and temporal picture in the overall water quality in a watershed in terms of the trend and intensity of contamination to help in quality monitoring [4].

Scholars such as those in [5] had stated that drinking water quality monitoring is an essential public health safety kit for all settings. Monitoring is defined as the 
programmed process of sampling, measurement and subsequent recording or signaling, or both, of various water characteristics, often with the aim of assessing conformity to specified objectives. Water quality monitoring for urban dwellings is a necessity considering that such environments are considered as being contaminous to drinking water as reported by $[6,7,8]$. This is partly due to the fact that drinking water is vulnerable to waste discharges $[9,10]$ hence its safety against pollution is needed at all times [11].

Drinking water safety history as sketched by [12] illuminated the depth and width of public suffering wrought by two of the oldest sanitary accidents known to us. The first was that of Broad Street water pump cholera outbreak in London by [13]. And the other, was that of Pforzheim Germany's typhoid epidemic that infected 4000 leading to 400 deaths. Both outbreaks were attributed to contaminated drinking water sources. Many investigators on drinking water quality contend that unsafe water affects human health in an epic proportion, often causing widespread devastations in its wake. Accordingly, there is a common unanimity that drinking water be ranked as a food item [14]. This requirement includes for the bottled water market [15]. The need to monitor and control drinking water purity was first proposed in the seminal work by [16]. But this condition is proving hard to fulfill going by the finding by [17] who reported that about a fifth of the world's population is still under the risk of water borne diseases.

Additionally, scholars such as [18] have stated that poor drinking water quality causes five million deaths annually on the global scale; forty percent of which are children below the age of five .Developing countries are the most vulnerable where about $80 \%$ of diseases are water related. In India for example, $21 \%$ of the communicable diseases are attributed to unsafe groundwater which serves $85 \%$ of the population according to [19]. Similarly, in the sub Saharan Africa region, groundwater forms an important source of drinking water particularly for the burgeoning demand in urban areas which is further driven by the surface water poverty $[20,21,22]$. But due to poor waste handling, freshwater contamination risk is raised thereby exposing urban inhabitants to mainly waterborne communicable diseases according to [23]. Occasionally, such outbreaks can become pandemic if they occur in a mega city like Dhaka [24].

A recent study by [25] on groundwater use in the eastern part of Kenya established a case of severely mottled enamel among Makindu town residents .They were found to be using a highly fluoridated groundwater which needed first to be treated before use. A previous related study by [26] on the contribution of solid waste to groundwater contamination in Nairobi city's Eastlands area established that the groundwater from zones in proximity to Dandora waste dumpsite is not suitable for human consumption. These two findings on groundwater quality in Kenya for example, do present to us a glimpse into a possible health risk associated with groundwater use, hence the need for quality monitoring.

In general, despite groundwater being an important source of human water needs, the resource is increasingly threatened, due to both natural and anthropogenic activities [27]. The impacts of heavy metals [28], the influence of pit latrines [29], impact of climate change [30] and the human influence [31] are major factors causing groundwater pollution in most aquifers of the world. This means that, the quality of groundwater must be monitored frequently to keep the population safe as asserted by [32]. For our study site, Langata sub County located to the south of Nairobi city centre; there is a growing dependence on vendor supplied groundwater by the local residents [33]. Little work has however been done to prepare the residents on vendor water quality tracking.

Drinking water quality information has always been masked in technical lingo as if the audience is solely the water resources' community who author them [34]. In the process, the general public's interpretation of water quality result is often dogged in confusion [35]. For this reason, the idea of water quality index (WQI) came into being to simplify the quality information's interpretation universally including for the rural communities [36]. An index is a comparison of a quality to a scientific or arbitrary standard or to a predetermined specifications [37]. Water quality index is taken to be an effective way to disseminate information on the quality of water to all categories of consumers [38]. It is thus a good parameter for assessment of the appropriateness of groundwater resource for certain use (irrigation, domestic or industrial) an area especially in the management of any arising abiotic stress condition like drought [39].

Several studies have defined WQI as a rating or grading tool that carries within it, the composite influence of different water quality parameters but mainly to ascertain the suitability of a given groundwater resource for human consumption [4,40,41,42]. Traditional assessment of groundwater quality involves the comparing of the levels of physico-chemical and biological parameters with those set by World Health Organization (WHO) alongside those of the host country's standard based on allocated water use or uses [43]. In other words, samples from a water source are collected and analyzed then the results are compared to guideline standards [44].

\section{Background}

\subsection{Overview}

Drinking water quality control is a pillar in the pursuit of public health safety demand. Key interest grew to monitor public water supply systems after John Snow's discovery, by epidemiological experiments that water was a major route for cholera transmission in London [13], Louis Pasteur's (1863) work on water based micro-organisms, and Robert Koch's (1863) findings regarding detection methods of micro-organisms in water. Towards the tail end of the $19^{\text {th }}$ century, a significant number of nations in Europe and America came up with unique ways for measuring drinking water quality for urban public water supply systems based majorly on disinfection by chlorine for pathogen micro-organisms inactivation [45].

In the period between 1950 and 1970 the World Health Organization (WHO) came up with standards for drinking water quality laying the scientific foundation for monitoring the quality of the treated water for delivery by water suppliers. Building on the same, WHO published 
supportive legislative and regulatory tools .This inspired European communities' development of water codes like ; European Union (EU): WHO Guidelines for Drinking water $\left(1^{\text {st }}\right.$ edition, 1984 , and $2^{\text {nd }}$ edition, 1993), and EU Directives 80/778/EC, and 98/83/EC (EC, 1998). These standards were in specific reference to standards of treated drinking water and on compliance monitoring. Water quality followed ex post testing, using spot sampling of the water in the distribution network. Such a procedure was able to control widespread waterborne diseases particularly those of bacterial origin.

The need for general water quality monitoring continued to rise for both the ambient and point of use conditions particularly to address the cases of water pollutions that were becoming rampant. This situation inspired the likes of [46] and later [44] to coin an index numbering system for rating water quality. This was to allow for close water quality monitoring. In its simplest form water quality monitoring was defined by these authors as the acquisition of quantitative and representative information about the physical, chemical and biological characteristics of a water body over time and space. This position was recently affirmed by [47].This was to allow the design of a monitoring net work to better reflect specific problems such as microbial or heavy metal contamination in the case of groundwater. Galvanized Iron (GI) piped distribution system is prone to corrosion attacks which means its delivered water also requires quality control [48].When fully developed for a water distribution system, WQI can actually facilitate the development of a National Sanitation Foundation on Water Quality Index (NSF-WQI) system to help disseminate information on water quality [49].

The emergence of WQI measurement system has today enabled local communities to discern the appropriateness of a water source for potability. The suitability of a water source for human consumption should ideally be specified based on the water source's Water Quality Index (WQI).This comes in the form of a single number (as a grade) that conveys the aggregated water quality at a given place and time, based on the combined contribution of all the measurable water quality parameters [50,51]. Scholars like those in [52] call it a dimensionless number.

The function of the WQI is to simplify the water quality data into easy to understand information suite which then becomes a utility to the public regarding drinking water safety [53].This is so important today considering that about 663 million people worldwide live without access to potable water [54].Many water quality indices have been developed by several national and international organizations like; National Sanitation Foundation Water Quality Index (NSFWQI), Weight Arithmetic Water Quality Index (WAWQI), Oregon Water Quality Index (OWQI), and the Canadian Council of Ministers of the Environment Water Quality Index (CCMEWQI) to help evaluate water quality in different regions $[44,55,56]$.The utility of WQI is not restricted to a locality noting that a global drinking water quality index was developed a decade ago by [57] for each eco-region of the world.

The problem of water quality does not discriminate between developed and poor nations as [58] reported on risk management for assuring safe drinking water. This work drew inspiration from an earlier related work on the lessons learnt from water borne disease outbreaks in 15 affluent nations in three decades from 70 case studies by [59]. And workers in [60] affirm that such a scenario exists because all water systems are vulnerable to contamination. The most risk prone networks are those that experience irregular flows [61]. Emergency situations also are known to render disaster zones to be susceptible to water contamination [62]. The collection method from communal water points or handling during transport or storage tanks can also cause contamination [63]. That is why [14] recommends that even the bottled water market should be under water quality control and monitoring.

Procedures for laboratory analysis to determine water quality are found in various publications. These include; USDA Handbook 60 by Richards, 1954, FAO Soils Bulletin 10 by Dewis and Freitas1970 and APHA, 2005-the advanced edition of APHA (1790 Broadway) which was primarily devoted to the physical and chemical examination of water, sewage, and industrial wastes. Later research on modeling of water quality in distributed systems was initiated in the agro-context; the optimal proportion of mixing of water from different sources [64] and improving poor quality water by the admixture of good-quality water [65] primarily in arid regions like the Arava valley in Southern Israel. As time passed by, USEPA in 1990, promulgated rules requiring that water quality standards must be confirmed at the consumer taps rather than at the sources' treatment plants. This initiated the need for water quality modeling, the development of the USEPA simulation water quantity and quality model EPANET [66].

Modeling has been the focus particularly on the chlorine and trihalomethanes in the distribution system. It has covered modeling water quality in tanks including design of chlorine booster systems to maintain the residual disinfectant levels in drinking water at the taps. Water quality models were used in hindcasting to assess water quality contamination events in distribution systems and in legal cases resulting from groundwater contamination. In this $21^{\text {st }}$ century however, water security has become a major driver in much of the research related to water quality modeling in distribution systems. The development of EPANET-MSX has allowed for the modeling of multiple interacting water sources [67].

Real-time water quality modeling has become an important direction in the form of hydro-informatics tool [68]. This is the reason, attempts have been made to use numerical modeling to produce spatial scale variation of the Water Quality Index (WQI) for different climatic zones in Asia [69]. Deployment of Geographic Information System by [70] to determine spatial distribution of groundwater quality parameters and to identify places with the best quality for drinking in Central Tunisia. Application of site specific water quality guideline to compute water quality indices in Newfoundland and Labrador by [71].

Groundwater Contamination Index was used by [72] to evaluate, map the degree of groundwater contamination and test its applicability in Southwestern Finland and Central Slovakia. This followed the classification presented by [73] when they developed water quality index for major Indian rivers. Later work by [74] on the potential of common forest and grassland management that introduced contaminants to human health through 
public drinking water sources in the United States. This helped in refining the approaches for assessing water quality conditions as confirmed in the works by [75]. Detailed literature book by worker in [76] on Water-Quality Indices, is a critical modern day reference on Water Quality Index systems for all communities.

\subsection{Local Scene}

Nairobi city is a home to over three million people; six percent of whom inhabit Langata sub County region. The drinking water demand of the city is met by Nairobi City Water and Sewerage Company (NCWSC); a contracted utility service provider by Athi Water Works Agency. Drought risk over the Horn of African region has however shifted residents' attention to groundwater as a source of supplication when the water utility system is down. The Water Quality Assurance Department of the company usually monitors the drinking water quality whose production follows the conventional best practice quality standards. The drinking water quality testing infrastructure is well laid out, see Figure 1 showing Ngethu Laboratory as an example. The quality control is done by sampling and testing at the; sources, treatment plants, bulk storage tanks, selected points within the distribution network and certain borehole sites see Figure 1. This is mainly to comply with the regulatory standards requirements. A consumer can also request for testing. The test results; monthly, annual and / or request based are submitted to Athi Water Agency (the water service level contracting body).

The same files are also copied to Water Services Regulatory Board (water service quality regulator). The department also makes a report on any corrective remedial measures undertaken if errors are detected [77]. For the Nairobi Aquifer Systems, Water Resources Management Authority (WaRMA) usually conducts regular monitoring of water quality. This, it does by collecting and testing water samples from a randomly selected number of boreholes to measure a chosen set of parameters for rating using the World Health Organization (WHO, 2008) guidelines and National Environment Management Authority drinking water standards' scale. For more details on the structure and challenges of water resources management system in Kenya, refer to the recent review work by [78]. For Lang'ata sub County area for example, [79] did a physico-chemical quality assessment of groundwater. The results suggested that groundwater from the boreholes in Langata area need to be treated to comply with WHO guidelines on drinking water standards. This is the same suggestion [80] reaffirmed by recommending for chlorine disinfection of borehole water in Nairobi city. She underscored the efficacy of chlorine disinfection in drinking water noting its unmatched legacy from 1900s and the widespread use including in the United States of America as recorded by [81].

\subsection{Related Work}

Water quality is a relative concept that reflects the measurable physical, chemical, and biological characteristics in relation to a specific use in terms of social and human welfare [82].This sort of social accountability is a measure of the suitability of water from a source to be admissible into for example, domestic use. The potability is typically defined by taste, odor, color, and the abundance of organic and inorganic substances that pose risks to human health.

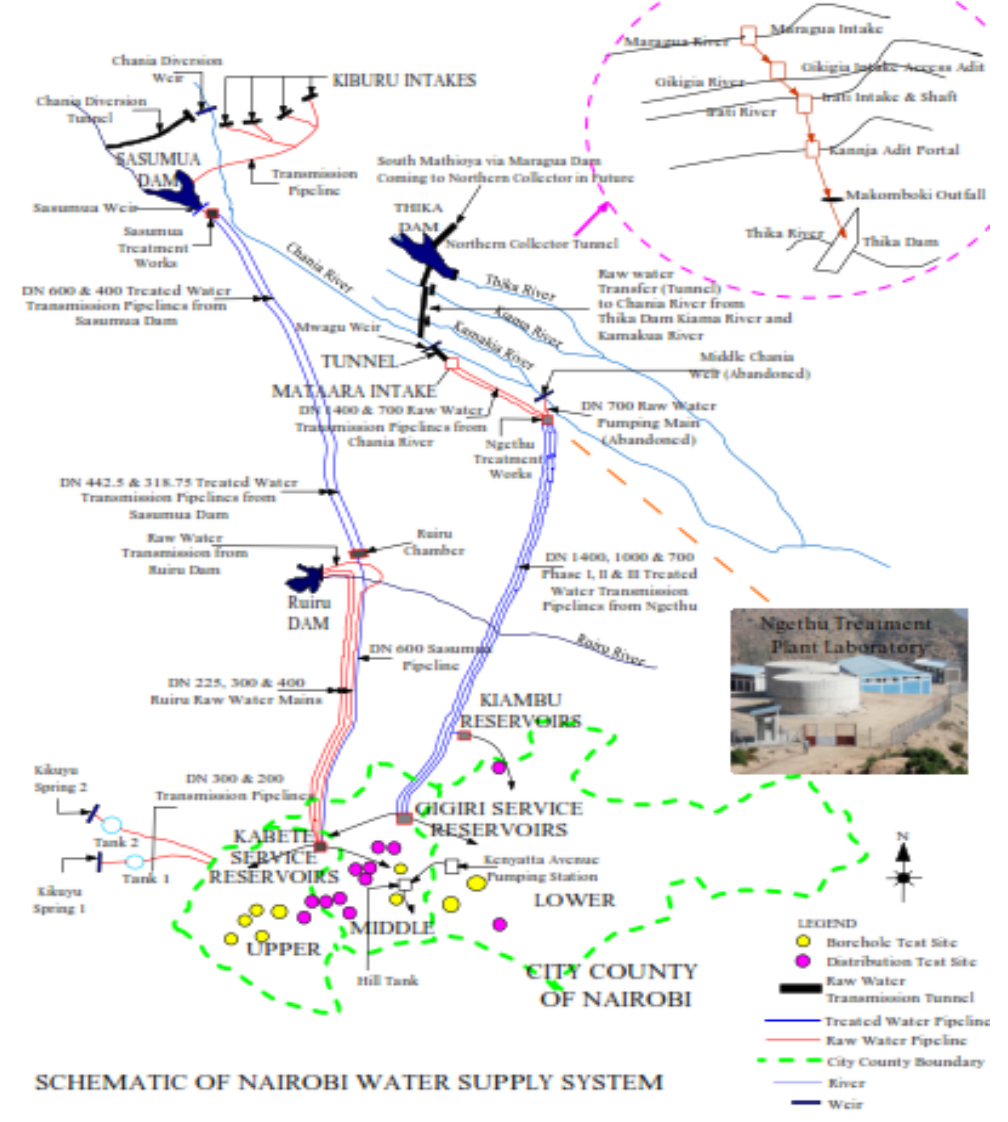

Figure 1. Drinking Water Quality Control Infrastructure for Nairobi City Water Supply System 
Standards for drinking water apply to water that is delivered to consumers after it has been treated to remove contaminants, but not to source water as it is withdrawn from surface or ground water [83]. Considerable treatment may be required to purify water meeting the ambient standard to comply with the drinking water standard for public use [84].

As effects on human health from exposure to contaminants in drinking water become better understood and as new substances are released to the environment, changes in drinking water standards can be expected in the future. But, worthy of noting is that each freshwater body has an individual pattern of physical and chemical characteristics which are determined largely by the climatic, geomorphological and geochemical conditions prevailing in the drainage basin and the underlying aquifer. Water quality assessment is the overall process of evaluation of the physical, chemical and biological nature of the water, whereas water quality monitoring is the collection of the relevant information [85].

One of the best ways to present water quality information is by the index computation method [86]. Index computation method first appeared in the financial engineering sector [87] as summation of items of financial performances into a single measurement or scale using laid down procedures. The four basic steps involve; selection of items or indicators, combining or transforming the variables into a sub-index, weighting of variables based on their importance to overall water quality and validating or aggregating the sub-index into single overall quality value that gives it meaning on a grading scale.

Since its adoption in water sector in the mid 19th century, it has continued to fertilize water quality monitoring, registering considerable successes in many places as that cited by [88] on New Zealand's rivers and streams. Freshwater quality control is a global issue due to its propensity to pollution [89].It is for this reason, that the foundation laid by [46] on water quality index calculation method using chemical and physical parameters in the United States of America will continue its relevance.

Horton's work inspired many studies like that by worker in [90] which produced an atlas of water quality for Bavaria (in West Germany) using chemical and biological parameters. The method was improved further in the study by [44]. From here; many scholars began applying water index calculation method in different places as time passed by $[91,92]$. The nine most common parameters that usually form part of water quality index computations are; Biochemical Oxygen Demand (BOD), Dissolved Oxygen, Fecal Coliform, Nitrate, Ph, Temperature Change, Total Dissolved Solids, Total Phosphates and Turbidity. Using these and other expanded characteristics, water quality index studies have followed two trajectories; either objective or subjective depending on the obtaining circumstances.

Such study approaches are known to produce results in one of the following categories; general water use advise [93], specific use; domestic, industrial or agricultural [94], water resources planning and management use [95], statistical analysis either by factor analysis or non-parametric multivariate transform [96]. The results have been used for water resource allocation because index value relates to a potential use for the water resource in question [97] including on monitoring of river water pollution levels [98].

The second use of WQI is to help in catchment area ranking as it helps in vulnerability evaluation of different areas [99] .Third; it can facilitate standards enforcements [71]. Fourth, it is used to present trend analysis since it is able to detect changes in water quality over time and space [4]. Fifth, the index may inform the public appropriately on water quality as it sums up different characteristics into a single value [91]. Water Quality Index can support scientific research. But the index method also has limitations which include; one, a possibility of data loss given there could be large amount of data. Secondly, the interrelationships between parameters are usually ignored.

And thirdly, a water sample from a site does not usually give a blanket quality rating of a water body. Despite these limitations, WQI has been applied in very many situations. In groundwater resource use planning and management, [100] developed a simple methodology based on multivariate analysis to create a groundwater quality index (GWQI), with the aim of identifying places with best quality for drinking within the Qazvin province, west central of Iran. The methodology was based on the definition of GWQI using average value of eight cation and anion parameters for 163 wells during a 3-year period. The GWQI map revealed that groundwater quality is suitable for drinking purposes. Created index map became a tool for a regional decision making for planners and managers.

In deciding the potability of a drinking water source,[2] used a review method to analyze the adequacy of Water Quality Index (WQI) computation method . The synthesis concluded that the absence of a globally accepted composite index of water quality has not hampered its application in several countries for water quality decision making. The original WQI formula has received improvements which have simplified it to allow for universal application. They concluded that the simplified version of WQI formula is capable of producing a more reliable picture of water quality. This same review method was used by [101] in India to analyze 13 papers; 9 of which covered lakes, and one each for a dam, a water treatment plant, a groundwater source and a river water quality assessment using index method. They stated that WQI method usually tests water parameters such as; temperature, pH, turbidity, salinity, nitrates and phosphates through weighting each on a WHO guidelines' scale before finally aggregating to produce a single value of water body quality class.

A chemical analyses study by [102] on groundwater and soil samples at Zakhera Village (Dakhla Oasis, Egyptian Western Desert) targeted to identify the suitability of water from each of the ten artesian wells for different uses. Water quality index (WQI), and saturation index (SI) indicated the suitability of these samples for different uses. For assessment of the potability of water sources, [103] recently undertook a study to evaluate the quality of 12 different water sources and 2 treated water used by a peri-urban town in the Southwest region of Nigeria. All the samples tested positive for faecal coliform 
bacteria and $E$. coli except one (treated water). The study recommended that microbial water quality parameters be included in all Water Quality Index (WQI) analyses in order to give the true status of the quality of a water resource.

In agriculture, [104] assessed groundwater quality for irrigation, using the principal chemical and physical quality parameters from 30 wells in Behbahan Plain, SW Iran. The study reported that groundwater classification on the basis of electrical conductivity showed that more than $85 \%$ of the samples taken were either 'unsuitable' or 'doubtful' water quality. Geochemical investigations indicate that the water chemistry was affected by processes including evaporation, water-rock interactions and human activities. In assessing groundwater potability, [105] tested water samples from 22 wells located in the rural areas surrounding Ingaldhal defunct copper mine in Chithradurga district of Karnataka state. They deployed Standard methods for physicochemical analysis of groundwater samples. Most of the samples analyzed were above the Guidelines set by Bureau of India Standards and (WHO, 2011) specifications for drinking water quality. Geographical Information System (GIS) capabilities were used to classify zones with acceptable groundwater quality for drinking purposes. The study concluded that groundwater from most parts of the study area was chemically unsuitable for drinking purpose.

The same method was earlier applied in Chithar Basin, Tamil Nadu, India by [106] which established the unsuitability of groundwater in the area for both drinking and irrigation purposes .In a similar fashion [107] had established the inappropriateness of Thanjavur city's groundwater. In the Djeffara aquifer system in SouthEastern Tunisia, [108] analyzed the area's groundwater chemical characteristics. The integration of various dataset indicated that the groundwater of the Djeffara aquifers within Northern Gabes is generally very hard, brackish and high to very high saline and alkaline in nature. The water suitability for drinking and irrigation purposes was evaluated by comparing the values of different water quality parameters with (WHO) guideline values for drinking water. The water was declared as unsuitable for the two uses.

In Oued Righ area in South-Eastern Algeria [109] assessed the suitability of its geothermal waters for irrigation. Groundwater samples were collected from twenty wells during two periods (January 2011 and May 2011). Total hardness revealed that a majority of the groundwater samples were in the very hard water category, total hardness values ranged from 59,40 to $106,40^{\circ} \mathrm{F}$. The EC classification indicated that $80 \%$ of CI groundwater samples were doubtful for irrigation and $20 \%$ were unsuitable for irrigation. Similarly, in Low-Isser plainBoumedres, Algeria, [110] assessed the groundwater quality for its suitability for domestic and agricultural uses. A total of 24 groundwater samples were collected and analyzed. The results showed that the groundwater in the area is unsuitable for the desired uses of either drinking water supply or crop irrigation.

In Iran's Birjand city, [111] investigated the association of toxicochemical and microbiological quality of bottled mineral water from 10 bottled water companies (10 brands) filling from natural springs and wells and packing in 1.5-liters plastic bottle sizes. One sample was randomly purchased in Khuzestan Province market from each brand, making a total of 10 samples. All the samples' quality met the WHO guidelines apart from nitrate concentrations which had no geologic reason, but anthropogenic attribution related to fertilizer use in the nearby farms. In trying to give direction on the applicability of analyses formula, [2] synthesized the requisites for these 4 most popular methods; National Sanitation Foundation (NSF) WQI formula, Canadian Council of Ministers of the Environment (CCME) WQI formula, Oregon WQI formula and Weighted Arithmetic WQI formula.

For the NSF method, it was clarified that these 9 parameters must always be available for its deployment in any study; temperature, $\mathrm{pH}$, turbidity, fecal coliform, dissolved oxygen, biochemical oxygen demand, total phosphates, nitrates and total solids. In our case, our data lacks any of the above listed parameters. For the CCME method, it was explained that each parameter needed a multiple set of samples from each site. At the very least, a minimum of four samples with at least four parameters are required for this method. Our data has only a single instance of data sample from 122 boreholes with the following 8 hydrochemical parameters; Potassium, Sodium, Calcium, Iron, Fluoride, Chloride, Sulphate and Electrical conductivity. Accordingly, the (CCME) WQI formula also could not be applied in our case.

It was clarified that Oregon WQI formula and (NSF) WQI formula have same requirement and that Oregon is a modified form of NSF. The Weighted Arithmetic WQI formula method was found to be suitable to our case. However; it has one limitation when it comes to the ranking and or grading procedure .In its case, the lower the value of WQI, the better - the water quality as an indicator of low level concentration of the combined parameters. The rest of the other 3 methods discussed above work in reverse. The aim of this study was to compute the water quality index (WQI) to establish the potability of the groundwater resource in Langata sub County. The final output is a site specific water quality guideline (SS-WQG) as was proposed by [112]. The expected outcome is that the study result will form part of a decision tool for groundwater use in the area. The rest of the sections of this paper are presented as follows; Section 3 presents methods, Section 4 presents results and discussions while section 5 details the conclusion.

\section{Method}

\subsection{Description of Study Area}

Langata sub County is found in the south of Nairobi city center, located approximately at $1^{\circ} 22^{\prime} 0^{\prime \prime} \mathrm{S}, 36^{\circ} 44^{\prime} 0^{\prime \prime}$ E. Its topography height range is between $1,600 \mathrm{~m}$ to $1,850 \mathrm{~m}$ above mean sea level. It covers an area of about $196.8 \mathrm{~km}^{2}$ in area, with a tolerable temperate tropical climate throughout the year see location map in Figure 2 below; 


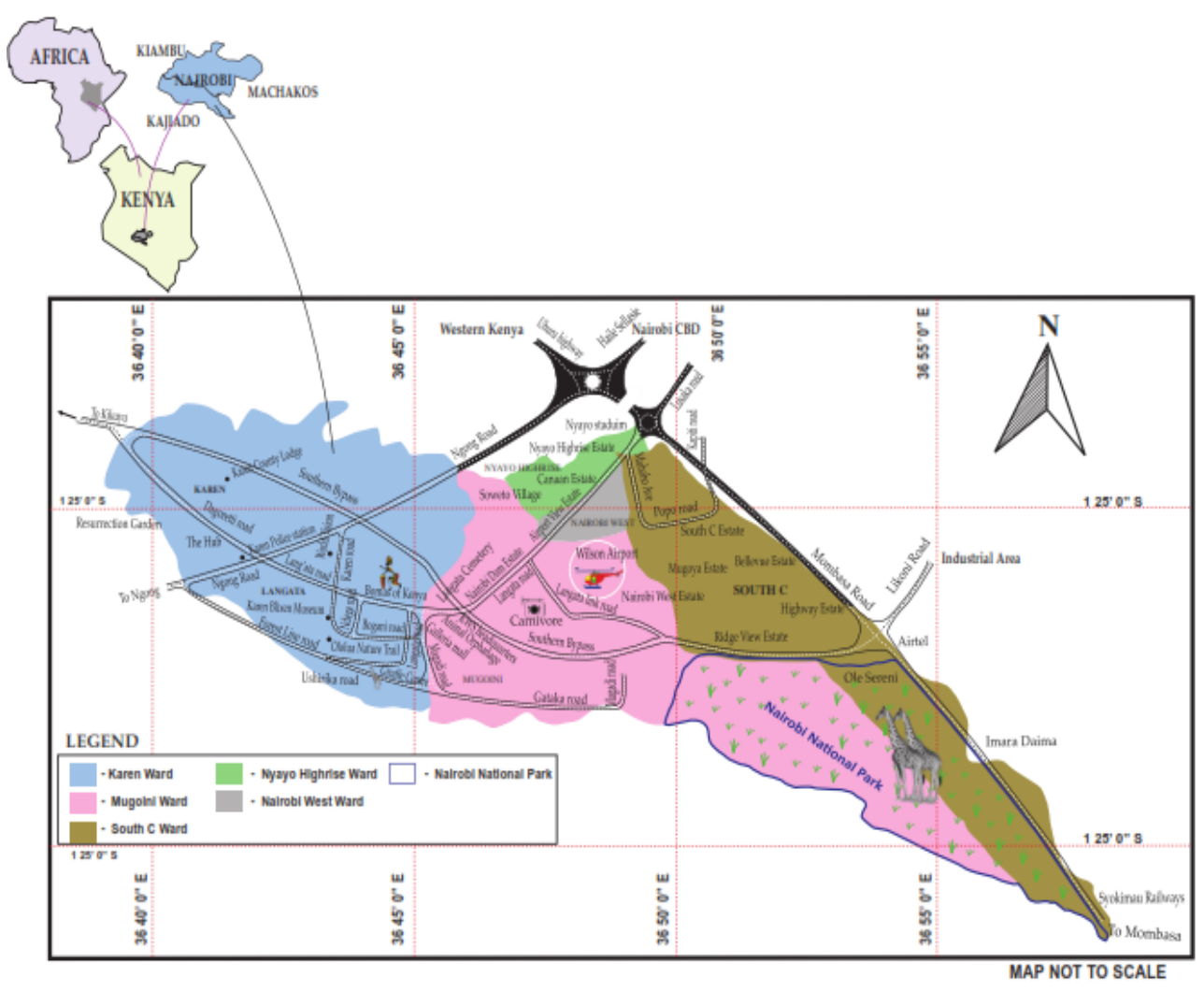

Figure 2. Location Map

\subsection{Population}

In a span of 50 years, the population of Nairobi city grew 12- fold, from around 293,000 inhabitants in 1960 to about 3.4 million in 2010 [21,113]. Between 1948 and 1999 workers in [114] also reported that the city population grew by $12.2 \%$. Equally, in terms of urbanization, the city was 3.84 square kilometers in 1910 compared to its current area of 696 square kilometers according to [115] as cited by [116]. For the study area [117] record shows that Langata sub County had 174,314 or $5.7 \%$ of the $3,078,180$ city's residents spread in 52,656 households. This rapid population growth and a steep urbanization rate for Nairobi city is described by [118] as being typical of a sub-Saharan Africa (SSA) urban centre characteristic.

\subsection{Geology}

Nairobi city area lies immediately east of the Kenyan rift valley. As such, volcanic, mainly lava flows dominate the geology of this area. These are of the Cenozoic age, overlying a basement of folded schists and gneisses of the Mozambique belt [119].

\subsection{Water Supply}

Nairobi City County imports $80 \%$ of its bulk water supply from Ndakaini and Sasumua dams located more than 50km away, see Figure 1 above. There are a number of challenges on the water supply system. Firstly, the current bulk system is not reliable due to drought impacts and siltation of reservoirs arising from deforestation in the upstream catchments. Further, there is a considerable inefficiency in the distribution system causing nearly 50\% unaccounted water associated mostly with pipe leakages and illegal connections. As a result, the city is under severe water rationing [120].

To cope, residents have turned to groundwater being supplied by both publicly and privately operated boreholes. On a larger scale, the government has also responded by drawing a robust long term water master plan for the city which is hinged on the Integrated Urban Water Management (IUWM) system up to year 2035 time horizon [121]. These ambitious plans are faced with additional challenges like; climate variability and uncertainty in the projected water supply and demands. This means, sources like the informal water market must also be included in the water plan. But their sources of water must be within the safety guidelines.

\subsection{Nairobi Groundwater Quality}

Nairobi boreholes abstract their water from unconfined, confined and perched aquifers with variable chemical quality. This means the water has varying geochemistry due to localized geochemical processes and possible faulting compartmentalization. A number of groundwater quality investigation studies have been done in different parts of the city most of which have established a high fluoride concentration beyond WHO recommended guidelines going further to propose for mixing groundwater with surface water in a ration of 1:1 to improve its potability. With the increasing water demand, the demand for groundwater is increasing in Nairobi. This demand must be met with a good safety plan in the form of water quality monitoring and control according to [122]. Nairobi city authorities has good infrastructure for water quality control, see for example Figure 2 above. What remains is to simplify the water quality information to the public. 


\subsection{Data}

Borehole drilling data was requested from Water Resources Management Authority (WaRMA) offices in Nairobi. We received borehole commissioning data for Langata sub County region for years 1982 to 2017 which had a total of 137 borehole files. On analysis using the perspective of hydrochemical parameters, showed that, 98 missed on one or more of the eight parameters; Potassium $\mathrm{K}^{+}$, Sodium $\mathrm{Na}^{+}$, Calcium $\mathrm{Na}^{+}$, Iron $\mathrm{Fe}^{2+}$, Flouride $\mathrm{F}^{-}$, Chloride $\mathrm{Cl}^{-}$, Sulphite $\mathrm{SO}_{4}^{-2}$ and Electrical Conductivity $\mathrm{Ec}(\mu \mathrm{S} / \mathrm{cm})$.This left 39 sample sites for analysis.

\subsection{Analysis Procedure}

From the previous work like that by [123], we selected 8 chemical parameters from 39 boreholes which resulted in 312 samples for analysis using the Weighted Arithmetic WQI computation method in 9 steps as follows;

1. Using Kenya Bureau of Standards on Drinking Water Quality (consistent with WHO guidelines), acceptable levels of concentration of each parameter was extracted as presented in Table 1.

2. Weighting of each of the parameters in the order of importance in drinking water quality measurement was done using a scale of 1 to 5 ; where 1 is the lowest value. After assigning the weights (Wa), the computation of the relative weight $(\mathrm{Wr})$ followed; being the result of the division of (Wa) by their total sum by using the following formula;
$\mathrm{Wr}=\mathrm{Wa} /\left(\sum \mathrm{Wa}\right)$

Table 1. Acceptable concentration levels (mg/l)

\begin{tabular}{|l|l|l|}
\hline $\mathrm{K}^{+}$ & Potassium & 50 \\
\hline $\mathrm{Na}^{+}$ & Sodium & 200 \\
\hline $\mathrm{Ca}^{2+}$ & Calcium & 250 \\
\hline $\mathrm{Fe}^{2+}$ & Iron & 0.3 \\
\hline $\mathrm{F}^{-}$ & Fluoride & 1.5 \\
\hline $\mathrm{Cl}^{-}$ & Chloride & 250 \\
\hline $\mathrm{SO}_{4}^{-2}$ & Sulphate & 400 \\
\hline $\mathrm{Ec}(\mu \mathrm{S} / \mathrm{cm})$ & Electrical Conductivity & 2500 \\
\hline
\end{tabular}

Table 2. Weight in order of Importance

\begin{tabular}{|l|c|c|c|}
\hline \multicolumn{2}{|c|}{ Parameter } & Wa & Wr \\
\hline $\mathbf{K}^{+}$ & Potassium & 2 & 0.118 \\
\hline $\mathbf{N a}^{+}$ & Sodium & 2 & 0.118 \\
\hline $\mathbf{C a}^{2+}$ & Calcium & 3 & 0.176 \\
\hline $\mathbf{F e}^{2+}$ & Iron & 1 & 0.059 \\
\hline $\mathbf{F}^{-}$ & Fluoride & 2 & 0.118 \\
\hline $\mathbf{C l}^{-}$ & Chloride & 4 & 0.235 \\
\hline $\mathbf{S O}{ }_{4}^{-2}$ & Sulphate & 1 & 0.059 \\
\hline $\mathbf{E c}(\boldsymbol{\mu S} / \mathbf{c m})$ & Electrical Conductivity & 2 & 0.118 \\
\hline \multicolumn{2}{|c|}{ Total } & 17 & 1 \\
\hline
\end{tabular}

3. The total sum of (Wr) is 1 (see Table 2).

4. Cleaning the data file (see Table 3 below).

Table 3. Quality Index Computation

\begin{tabular}{|c|c|c|c|c|c|c|c|c|c|c|}
\hline \multirow[b]{2}{*}{ S/NO } & \multirow[b]{2}{*}{ FILE NUMBER } & \multicolumn{9}{|c|}{ WQI Computations } \\
\hline & & $\mathbf{K}+$ & $\mathrm{Na}+$ & $\mathrm{Ca} 2+$ & $\mathrm{Fe} 2+$ & F- & Cl- & SO4-2 & $\mathrm{Ec}(\boldsymbol{\mu S} / \mathbf{c m})$ & WQI $\left\{\sum \mathrm{SI}\right\}$ \\
\hline 16 & WRMA/30/NRB/3AA/12381/G & 2.35 & 3.46 & 0.68 & 11.18 & 10.82 & 1.98 & 0.02 & 1.67 & 32.16 \\
\hline 132 & WRMA/30/NRB/3AA/10079/G & 0.24 & 6.12 & 0.45 & 8.82 & 21.18 & 1.60 & 0.04 & 2.32 & 40.76 \\
\hline 231 & WRMA/30/NRB/3BA/614/G & 0.89 & 4.62 & 0.00 & 1.37 & 67.45 & 1.04 & 0.02 & 1.77 & 77.16 \\
\hline 237 & WRMA/30/NRB/3BA/13193/G & 1.67 & 5.01 & 0.56 & 0.20 & 78.43 & 4.24 & 0.09 & 1.60 & 91.80 \\
\hline 240 & WRMA/30/NRB/3BA/10713/G & 0.31 & 9.56 & 0.17 & 9.61 & 50.98 & 5.74 & 0.67 & 3.57 & 80.60 \\
\hline 243 & WRMA/30/NRB/3BA/10791/G & 2.19 & 6.05 & 1.13 & 0.00 & 51.76 & 0.47 & 2.21 & 1.78 & 65.59 \\
\hline 272 & WRMA/30/NRB/3BA/12030/G & 1.41 & 4.41 & 0.06 & 5.88 & 38.43 & 1.79 & 0.18 & 1.34 & 53.51 \\
\hline 278 & WRMA/30/NRB/3BA/10615/G & 0.33 & 3.62 & 0.79 & 8.24 & 9.80 & 1.60 & 0.06 & 1.71 & 26.16 \\
\hline 338 & WRMA/30/NRB/3AA/13794/G & 2.05 & 6.05 & 1.98 & 29.41 & 19.61 & 6.59 & 0.21 & 2.40 & 68.29 \\
\hline 373 & WRMA/30/NRB/3BA/13916/G & 2.42 & 5.44 & 1.13 & 3.33 & 5.73 & 2.45 & 0.17 & 2.56 & 23.23 \\
\hline 394 & WRMA/30/NRB/3BA/12727/G & 5.65 & 5.06 & 2.19 & 3.92 & 30.59 & 7.15 & 0.32 & 1.81 & 56.69 \\
\hline 396 & WRMA/30/NRB/3AA/13581/G & 7.06 & 5.59 & 0.36 & 0.59 & 10.98 & 3.67 & 0.14 & 1.79 & 30.17 \\
\hline 401 & WRMA/30/NRB/3AA/13169/G & 5.88 & 5.29 & 1.84 & 1.96 & 30.59 & 7.06 & 0.32 & 2.35 & 55.30 \\
\hline 416 & WRMA/30/NRB/3AA/13580/G & 3.53 & 4.73 & 0.11 & 16.86 & 69.73 & 1.69 & 0.14 & 1.88 & 98.68 \\
\hline 445 & WRMA/30/NRB/3AA/84/G & 2.49 & 6.50 & 0.51 & 0.39 & 26.67 & 1.69 & 0.10 & 1.46 & 39.82 \\
\hline 463 & WRMA/30/NRB/3AA/184/G & 2.94 & 2.94 & 1.02 & 4.12 & 20.00 & 2.26 & 0.11 & 1.73 & 35.11 \\
\hline 465 & WRMA/30/NRB/3AA/187/G & 2.19 & 3.00 & 0.79 & 0.59 & 2.35 & 1.04 & 0.18 & 1.27 & 11.40 \\
\hline 484 & WRMA/30/NRB/3BA/208/G & 2.14 & 3.10 & 0.56 & 5.06 & 9.41 & 1.51 & 0.06 & 1.41 & 23.25 \\
\hline 492 & WRMA/30/NRB/3AA/217/G & 0.38 & 2.94 & 1.47 & 0.78 & 21.18 & 2.45 & 0.03 & 1.82 & 31.04 \\
\hline 510 & WRMA/30/NRB/3AA/239/G & 0.33 & 4.81 & 0.17 & 2.35 & 47.06 & 1.32 & 0.14 & 1.78 & 57.96 \\
\hline 511 & WRMA/30/NRB/3AA/240/G & 6.16 & 5.48 & 0.34 & 0.59 & 15.69 & 3.01 & 0.12 & 2.49 & 33.88 \\
\hline 530 & WRMA/30/NRB/3AA/256/G & 1.98 & 4.19 & 0.28 & 19.22 & 12.55 & 1.41 & 0.09 & 1.69 & 41.40 \\
\hline 540 & WRMA/30/NRB/3AA/271/G & 2.35 & 3.45 & 1.41 & 6.86 & 4.86 & 1.88 & 0.33 & 2.36 & 23.51 \\
\hline 575 & WRMA/30/NRB/3AA/326/G & 2.07 & 3.38 & 1.30 & 1.76 & 61.18 & 1.88 & 0.05 & 2.20 & 73.83 \\
\hline 584 & WRMA/30/NRB/3AA/335/G & 1.88 & 3.41 & 1.41 & 2.16 & 20.39 & 2.07 & 0.12 & 1.98 & 33.42 \\
\hline 612 & WRMA/30/NRB/3AA/363/G & 4.00 & 3.55 & 0.79 & 0.20 & 12.71 & 1.51 & 0.03 & 1.85 & 24.63 \\
\hline 622 & WRMA/30/NRB/3AA/377/G & 4.49 & 4.43 & 0.37 & 0.98 & 8.24 & 5.08 & 0.26 & 5.60 & 29.45 \\
\hline
\end{tabular}




\begin{tabular}{|c|c|c|c|c|c|c|c|c|c|c|}
\hline & & \multicolumn{9}{|c|}{ WQI Computations } \\
\hline S/NO & FILE NUMBER & $\mathbf{K}+$ & $\mathrm{Na}^{+}$ & Ca2+ & Fe2+ & F- & Cl- & SO4-2 & $E c(\mu S / c m)$ & WQI $\left\{\sum \mathrm{SI}\right\}$ \\
\hline 633 & WRMA/30/NRB/3AA/404/G & 2.12 & 4.18 & 0.68 & 14.12 & 36.08 & 1.60 & 0.14 & 1.84 & 60.75 \\
\hline 636 & WRMA/NRB/BH/952 & 2.35 & 3.53 & 0.62 & 2.94 & 14.90 & 1.13 & 0.10 & 1.63 & 27.20 \\
\hline 651 & WRMA/30/NRB/3AA/403 & 1.04 & 4.85 & 0.85 & 5.49 & 14.90 & 3.39 & 0.17 & 2.10 & 32.79 \\
\hline 665 & WRMA/30/NRB/3BA/14332/G & 1.65 & 4.71 & 0.17 & 11.76 & 83.76 & 1.79 & 0.14 & 2.00 & 105.99 \\
\hline 676 & WRMA/30/NRB/3AA/14036/G & 1.13 & 3.76 & 1.41 & 0.02 & 39.22 & 3.76 & 0.07 & 1.71 & 51.08 \\
\hline 706 & WRMA/30/NRB/3BA/475/G & 2.05 & 4.65 & 0.11 & 1.71 & 52.55 & 2.35 & 0.12 & 1.51 & 65.04 \\
\hline 757 & WRMA/30/NRB/3AA/589/G & 0.80 & 5.00 & 0.17 & 0.20 & 45.49 & 1.13 & 0.00 & 2.02 & 54.81 \\
\hline 832 & WRMA/30/NRB/3AA/683/G & 2.82 & 5.21 & 0.23 & 0.20 & 86.27 & 1.60 & 0.15 & 2.13 & 98.60 \\
\hline 853 & WRMA/30/NRB/3BA/10026/G & 1.60 & 4.28 & 0.71 & 5.88 & 47.06 & 6.40 & 0.29 & 1.42 & 67.63 \\
\hline 1102 & WRMA/30/NRB/3BA/10946/G & 0.26 & 3.88 & 0.28 & 5.10 & 25.88 & 0.85 & 0.09 & 1.63 & 37.97 \\
\hline 1383 & WRMA/30/NRB/3AA/15389/G & 2.28 & 7.18 & 0.85 & 8.43 & 130.20 & 11.29 & 0.54 & 2.60 & 163.38 \\
\hline 1412 & WRMA/30/NRB/3AA/14374/G & 1.29 & 17.56 & 0.00 & 7.84 & 9.41 & 5.74 & 0.67 & 7.52 & 50.04 \\
\hline \multicolumn{2}{|c|}{ Maximum } & 7.06 & 17.56 & 2.19 & 29.41 & 130.20 & 11.29 & 2.21 & 7.52 & 163.38 \\
\hline \multicolumn{2}{|c|}{ Average } & 2.28 & 5.00 & 0.72 & 5.39 & 34.46 & 2.95 & 0.22 & 2.16 & 53.18 \\
\hline \multicolumn{2}{|c|}{ Minimum } & 0.24 & 2.94 & 0.00 & 0.00 & 2.35 & 0.47 & 0.00 & 1.27 & 11.40 \\
\hline
\end{tabular}

5. Normalization of the quality value for each parameter in each borehole site is done using the formula

$$
\mathrm{Qa}=\mathrm{Ca} / \mathrm{Sa}
$$

Where Qa is the normalized Quality rating for the specific parameter, $\mathrm{Ca}$ is the concentration level measured for the particular parameter for the same borehole and $S_{a}$ is the acceptable level for the particular parameter as per the standards (refer to procedure 1 above). In our case, to get measured value of each parameter's concentration level (Ca ) using Table 3 above, divide the product of normalized quality value $\left(\mathrm{Q}_{\mathrm{a}}\right)$ and maximum allowable concentration by the product of 100 and relative weight (Wr). For example, in Table $3, \mathrm{~K}^{+}$Sub Index value $\left(\mathrm{Q}_{\mathrm{a}}\right)$ is 2.35 for borehole No.16. In Table 1, Maximum Standard concentration for $\mathrm{K}^{+}$is 50 , relative weight $(\mathrm{Wr})$ for $\mathrm{K}^{+}$in Table 2 is 0.118 , therefore the concentration is $(2.35 \mathrm{x}$ $50) /(100 \times 0.118)=10$.

6. To compute the individual parameter's weighted quality, multiply the normalized quality value (Qa) for each parameter $\mathrm{x} 100$ and relative weight (Wr).For the case of borehole No.16, for $\mathrm{K}^{+}$for example, Qa is (10/50) $=0.2$ and $\mathrm{Wr}$ from Table 2 for $\mathrm{K}^{+}$is 0.118 . Therefore, the weighted quality value of $\mathrm{K}^{+}$is $(0.2 \times 100 \times 0.118)=2.35$, which is the same value presented in Table 3 above.

7. The Sub Index quality value for each borehole is the summation of weighted quality value of the eight parameters for each borehole. For example, in borehole No.16 in Table 3 above, the Sub Index quality value is 32.16.

8. The Water Quality Index for the study area is read in three levels; as maximum, minimum and average. In our case, borehole No.1383 has the maximum Sub Quality Index value at 163.38 and borehole No.465 has the minimum Sub Quality Index value at 11.40 as read from Table 3, while the average or the Overall Water Quality Index value for the boreholes in the study site is 53.18 as presented in Table 3 above.

9. Usually the average or the Overall Water Quality Index value generated in step 8 above is the one used to rank or grade the general water quality of an area. In our case, Table 4 below.
Table 4. Water Quality Grading Scale

\begin{tabular}{|l|c|c|c|}
\hline Ranking & WQI -\% Scale & WQI & GRADE \\
\hline Excellent & $<20$ & $<0.2$ & A \\
\hline Very Good & $20-40$ & $0.2-0.4$ & B \\
\hline Good & $40-60$ & $0.4-0.6$ & C \\
\hline Fairly Good & $60-80$ & $0.6-0.8$ & D \\
\hline Suitable & $80-100$ & $0.8-1.0$ & E \\
\hline Unsuitable & $>100$ & $>1.0$ & F \\
\hline
\end{tabular}

10. For graphical presentation of the water quality values, we used the thinking by [92] the values generated in step 7 as in Table 3 for each borehole to plot using Surfer Software Version 6 water quality maps for the study area. We generated a total of 9 maps; one for the overall groundwater quality and the other eight for the performance of each parameter over the area.

\section{Results and Discussion}

\subsection{Overall Groundwater Quality Index (WQI)}

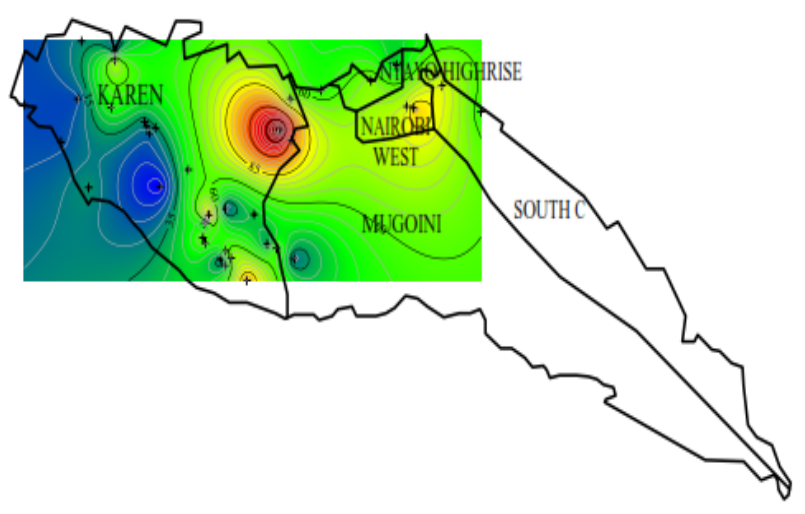

Figure 3. Overall Water Quality Index Display

Using the procedure outlined in section 3.7 above, the average WQI for Langata sub County's groundwater was calculated as 53.18, see Table 3 . The best ground water 
quality is found in Miotoni area of Karen, see Figure 3, with WQI of 11.40, see Table 3. The unsuitable groundwater with WQI of 163.38 is found around Langata area within Karen Ward near to Bomas of Kenya extending to Mugoini Ward. Nairobi West Ward also has a spot of not so good quality water, See Figure 3. The unsuitable groundwater should not be used for human consumption.

\subsection{Concentration of Potassium}

The concentration of Potassium within the study area ranges from 1-30 mg/l (see step 5 and Table 3).The entire study site has a concentration falling within permissible limit. Potassium is described as being both an electrolyte and a nutrient. It works with Sodium to maintain the body's water balance, nerve function; muscle control and blood pressure control. Excessive ingestion of Potassium is not good for health. Karen, Nyayo High rise and South C wards have higher spots of concentration but within the limit.

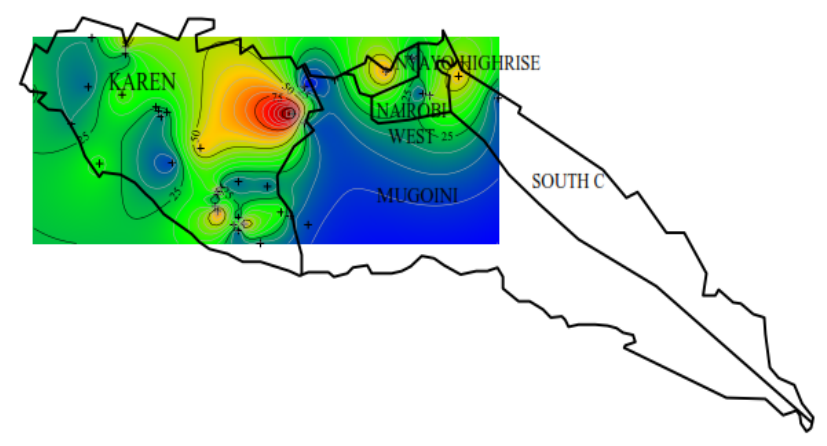

Figure 4. Concentration of Potassium

\subsection{Concentration of Sodium}

The concentration of Sodium in the study area ranges from 50-298.5mg/l (see step 5 and Table 3). One single borehole out of the 39 analyzed had concentration above 250mg/l permissible level. High ingestion of Sodium is not good for health with regards particularly to hypertension. See Figure 5 for the spatial display. Karen ward has a higher Sodium concentration spot followed by South C ward.

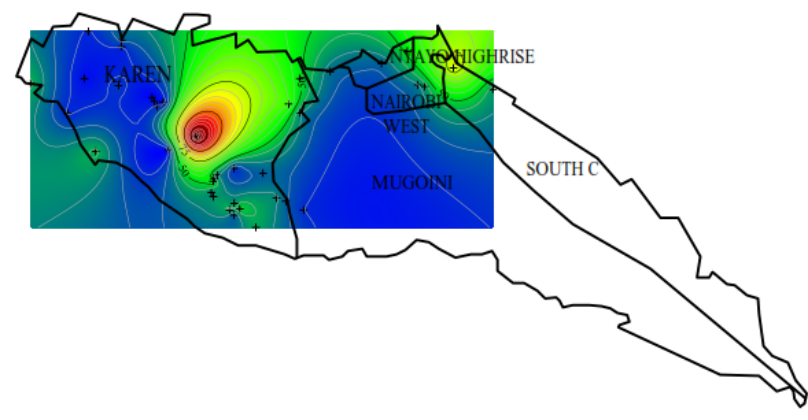

Figure 5. Concentration of Sodium

\subsection{Concentration of Calcium}

The concentration of the Calcium in the study area ranges between $0.01-30 \mathrm{mg} / \mathrm{l}$ which is within the permissible limit of 250mg/l. Usually, 99\% of Calcium in the body functions as the structural element in bones and teeth. The other $1 \%$ performs vital physiological processes. Inadequate intake of Calcium is associated with increased risk for diseases such as kidney stones. Excessive intake of Calcium can cause crippling skeletal fluorosis and possible increased bone fracture risk. See Figure 6 for spatial display in which Karen Ward is shown to have elevated concentration of Calcium but within limit.

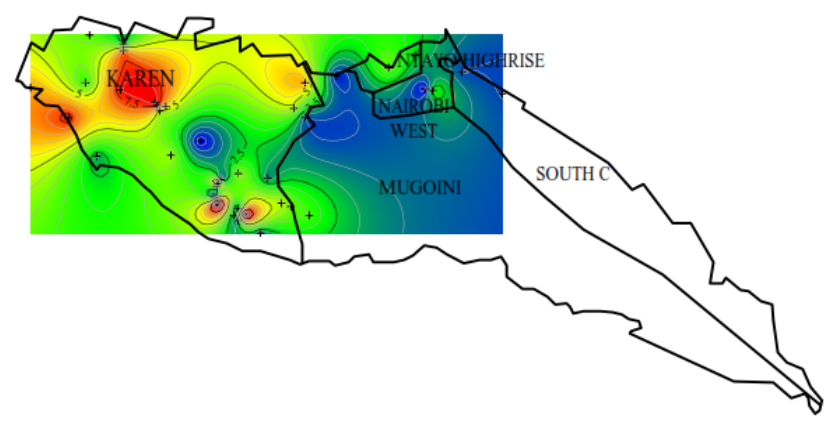

Figure 6. Concentration of Calcium

\subsection{Concentration of Iron}

Iron concentration of groundwater samples in the study area varies from $0.001-1.5 \mathrm{mg} / \mathrm{l}$, see Table 3 . The standard acceptable limit is $0.3 \mathrm{mg} / \mathrm{l}$. Only 12 (30\%) of boreholes have higher concentration above permissible limit, see Table 3. High Iron contamination is an indication of the presence of ferrous salts that precipitate as insoluble ferric hydroxide and settle out as rusty silt. Toxic effects may result from the ingestion of large quantities of iron. At concentrations above $0.3 \mathrm{mg} / \mathrm{l}$, iron can stain laundry and plumbing fixtures and cause undesirable tastes. Iron may also promote the growth of certain microorganisms; leading to the deposition of a slimy coat in piping. The variation of Iron concentration in the study period is shown in Figure 7, where Karen and Mugoini wards share the elevated concentrations

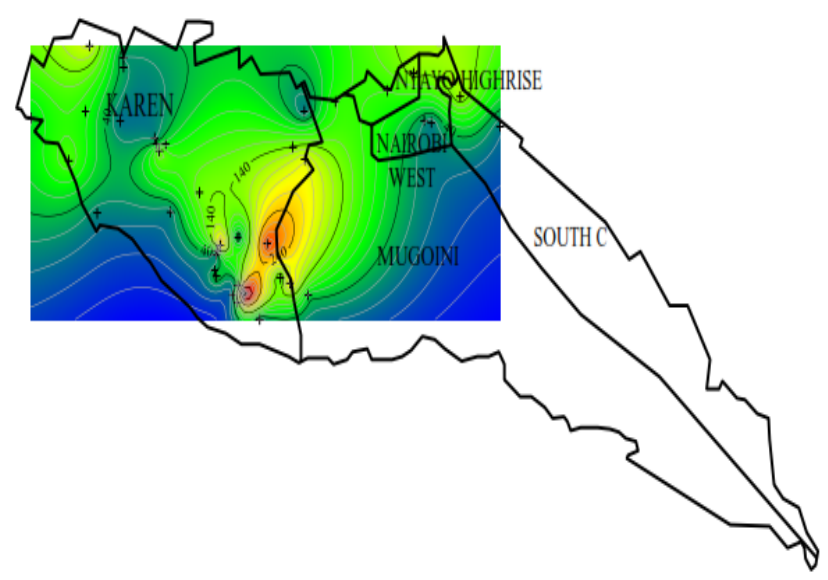

Figure 7. Iron Concentration

\subsection{Concentration of Fluoride}

The Fluoride concentration in Langata groundwater ranges from $0.30-16.6 \mathrm{mg} / \mathrm{l}$. Only 9 out of the 39 boreholes sampled have their Fluoride concentration being 
within the acceptable limit of $1.5 \mathrm{mg} / \mathrm{l}$. The variation of fluoride concentration is dependent on a variety of factors such as the amount of soluble and insoluble fluoride in source rocks, the duration of contact of water with rocks and soil temperature, rainfall, oxidation- reduction process.

The presence of small quantities of fluoride in drinking water prevents tooth decay. Fluoride is poisonous at high levels. High levels may cause easily noticeable dental fluorosis and skeletal damages, the latter being not clinically obvious until advanced stages have occurred. Fluorosis is an aesthetic concern because discolored teeth could affect an individual's facial appearance and sense of wellbeing. Groundwater with high concentration should be deflouridated for drinking. The spatial variation of Fluoride in the study area is shown in Figure 8 in which Karen and Nairobi West wards indicate to have elevated concentrations.

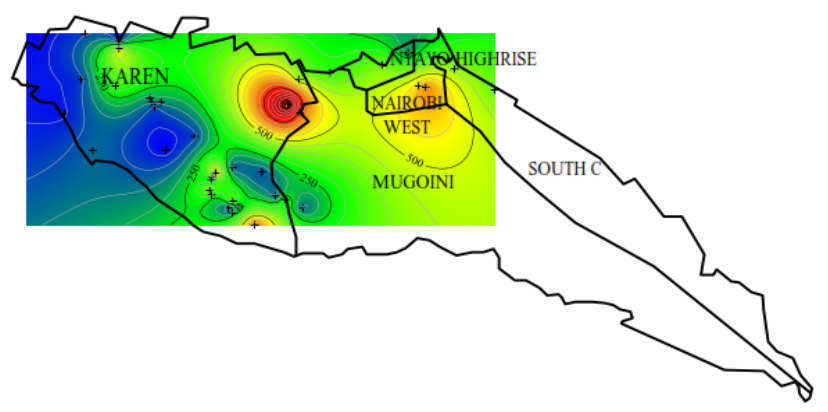

Figure 8. Fluoride Concentration

\subsection{Concentration of Chloride}

Chloride concentration in Langata groundwater is in the range of $5-120 \mathrm{mg} / \mathrm{l}$, see Table 3 which is within the permissible limit of $250 \mathrm{mg} / \mathrm{l}$ as per Kenyan Standards as well as WHO Standards, see Table 1 . The variation of Chloride concentration in the study area is shown Figure 9. Chloride concentration in groundwater is usually high where the temperature is high and rainfall is less. Spots of elevated levels are found within Karen, Nyayo High rise and South $\mathrm{C}$ wards.

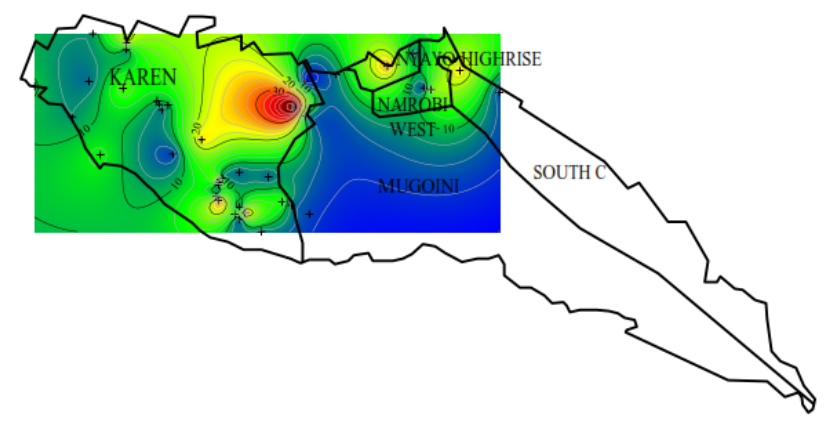

Figure 9. Chloride concentration

\subsection{Concentration of Sulphate}

Sulphate concentration in Langata groundwater ranges from $0.29-150 \mathrm{mg} / \mathrm{l}$ which is within the permissible limit of $400 \mathrm{mg} / \mathrm{l}$ as per Kenyan Standards and $250 \mathrm{mg} / \mathrm{l}$ as per WHO Standards. Ingestion of water containing high levels of Sulphate may cause diarrhea. The variation of Sulphate in the study period is shown in Figure 10 with Karen ward exhibiting the highest level.

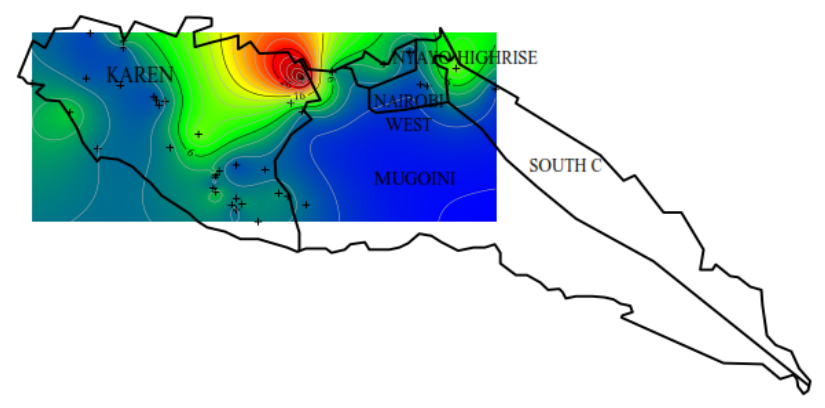

Figure 10. Sulphate Concentration

\subsection{Electrical Conductivity}

The Electrical Conductivity (EC) of the groundwater in Langata sub County, ranges from 270-1598 $\mu \mathrm{S} / \mathrm{cm}$ which is within the permissible limit of 2500 , see Table 1.Conductivity is an indicator of other water quality problems. Water with high mineral content usually exhibits a higher conductivity and this is a general indication of high dissolved solid concentration of the water. The variation of Electrical Conductivity in the study area is shown in Figure 11 with Karen Ward having the highest EC.

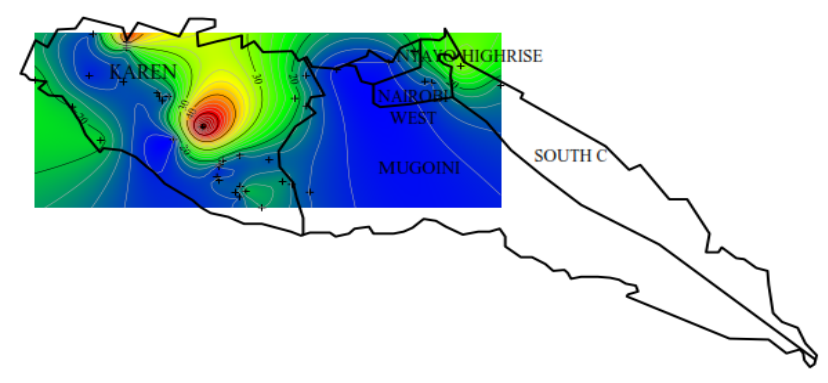

Figure 11. Electrical Conductivity

\section{Conclusion}

After the analysis of the chemical parameters for each of the 39 sample boreholes' waters, interpretation and discussions of the numerical quality index values and their spatial displays, the following conclusions have been drawn for the quality of groundwater in Langata sub County, Nairobi city. Generally, the groundwater is of good quality with WQI of 53.18 (on a scale of 1 to 100; with one being Excellent and 100 at the margin to unsuitability).Most boreholes yield suitable water with moderate mineral or dissolved salts. Water is soft in majority of the boreholes. Since Sulphate and Chloride are within permissible concentration levels, it shows that, the area has no contamination of groundwater due to percolation of polluted surface water.

It is only Fluoride concentration where $77 \%$ of boreholes fall above standards, which requires that, their water be mixed with surface water for dilution to permissible level , preferable using a ration of 1:1 as [122] had recommended. The WQI falls on GOOD range hence suitable for domestic use. The study recommends that the 
groundwater be disinfected to protect the consumers from the perils of contaminations. A comprehensive analysis involving physical, chemical and biological parameters also need to be done to give a proper groundwater quality assessment.

\section{Acknowledgements}

The authors are grateful for the moral support extended by the Institute for Climate Change and Adaptation of the University of Nairobi during the study period. This study received no funding and so each of the authors has no attached interest over the same.

\section{References}

[1] Lofrano, G., \& Brown, J. (2010). Wastewater management through the ages: A history of mankind. Science of The Total Environment, 408(22), 5254-5264.

[2] Shweta Tyagi, Bhavtosh Sharma, Prashant Singh, and Rajendra Dobhal, (2013). "Water Quality Assessment in Terms of Water Quality Index.” American Journal of Water Resources 1, no. 3 (2013): 34-38.

[3] Ferrier, R. C., \& Edwards, A. C. (2002). Sustainability of Scottish water quality in the early 21st Century. Science of The Total Environment, 294(1-3), 57-71.

[4] Boyacioglu, H. (2009). Development of a water quality index based on a European classification scheme. Water SA, 33(1).

[5] Vieira, J.M.P (2005). Water safety plans: methodologies for risk assessment and risk management in drinking-water systems. The fourth inter-celtic colloquium on hydrology and management of water resources.

[6] Prescott, Samuel Cate and Charles-Edward Amory Winslow (1904). Elements of Water Bacteriology with Special Reference to Sanitary Water Analysis

[7] Scott J. McGrane (2015). Impacts of urbanization on hydrological and water quality dynamics, and urban water management: a review, Hydrological Sciences Journal.

[8] Al-Kharabsheh, A. and Ta'any, R., 2003. Influence of urbanization on water quality deterioration during drought periods at South Jordan. Journal of Arid Environments 53, pp. 619-630.

[9] Edberg, S. C., Rice, E. W., Karlin, R. J., \& Allen, M. J. (2000). Escherichia coli: the best biological drinking water indicator for public health protection. Journal of Applied Microbiology, 88(S1), 106S-116S.

[10] Mbui et al. (2016). The State of Water Quality in Nairobi River, Kenya. Asian J. Research Chem. 9(11). 2016.

[11] McKee J. E. and Wolf, H. W. (1963) Water Quality Criteria. State Water Quality Control Board, Sacramento, Calif. Publicatmn No. 3-A.

[12] Szewzyk, U., Szewzyk, R., Manz, W., \& Schleifer, K.-H. (2000). Microbiological Safety of Drinking Water. Annual Review of Microbiology, 54(1), 81-127.

[13] Snow, J. (1855). On the Mode of Communication of Cholera. John Churchill. England.

[14] Del Rosario EJ, Migo VP, Clemente EM, Cerbolles MTC, Tecson-Mendoza EM (2012). Purification and quality of drinking water: Issues and concerns. Transactions of the National Academy of Science and Technology PHL 34.

[15] Soroush, M., Ehya, F., \& Maleki, S. (2016). Major and trace elements in some bottled water brands from Khuzestan Province market, SW Iran, and accordance with national and international standards. Environmental Earth Sciences, 75(4).

[16] Frost et al. 1915. Some considerations in estimating the sanitary quality of water supplies [withdiscussion]. Journal (American Water Works Association), Vol. 2, No. 4 (DECEMBER, 1915), pp.712-734.

[17] Gail, Krantzberg, and Tanik, Aysegul. (2010). Book Recommendation: Advances in Water Quality Control. Journal of Water Resource and Protection. 02.
[18] Chin, David A. (2006). Water-quality engineering in natural systems. Published by John Wiley \& Sons, Inc., Hoboken, New Jersey.

[19] Iyer et al., 2014. Drinking Water Quality Surveillance in a Vulnerable Urban Ward of Ahmedabad. Health, 6, 1165-1171.

[20] Garriga, R. G., \& Foguet, A. P. (2011). Application of a revised Water Poverty Index to target the water poor. Water Science and Technology, 63(6), 1099-1110.

[21] Jacobsen, Michael, Michael Webster, and Kalanithy Vairavamoorthy, eds. 2012. The Future of Water in African Cities: Why Waste Water? Directions in Development. Washington, DC: World Bank. License: Creative Commons Attribution CC BY 3.0.

[22] Hatem, Jemmali, 2018. "Water Poverty in Africa: A Review and Synthesis of Issues, Potentials, and Policy Implications," Social Indicators Research: An International and Interdisciplinary Journal for Quality-of-Life Measurement, Springer, vol. 136(1), pages 335-358, February.

[23] Lapworth, D. J., Nkhuwa, D. C. W., Okotto-Okotto, J., Pedley, S., Stuart, M. E., Tijani, M. N., \& Wright, J. (2017). Urban groundwater quality in sub-Saharan Africa: current status and implications for water security and public health. Hydrogeology Journal, 25(4), 1093-1116.

[24] Shamimuzzaman, M., Nayeem, R.H., Ara, N., Rahman, M.M., Jahid, M.I.K. and Hasan, M.N. (2019). Physico-Chemical and Microbiological Quality Assessment of Supply Water around Dhaka City, Bangladesh. Journal of Water Resource and Protection, 11, 280295.

[25] Mbithi, F.M, Patrick CK, Peter GN. (2017). Assessment of the Impact of Groundwater Fluoride on Human Health: A Case Study of Makindu District in Kenya. J Earth Sci Clim Change 8: 396.

[26] Musoni, Bruce (2016). Impact of Solid Wastes on Groundwater Quality in Dandora, Nairobi County, Kenya. MSc. Thesis- Kenyatta University.

[27] Kurwadkar, S. (2017). Groundwater Pollution and Vulnerability Assessment. Water Environment Research, 89(10), 1561-1577.

[28] Edokpayi, J. N., Enitan, A. M., Mutileni, N., \& Odiyo, J. O. (2018). Evaluation of water quality and human risk assessment due to heavy metals in groundwater around Muledane area of Vhembe District, Limpopo Province, South Africa. Chemistry Central Journal, 12(1).

[29] Graham, J. P., \& Polizzotto, M. L. (2013). Pit Latrines and Their Impacts on Groundwater Quality: A Systematic Review. Environmental Health Perspectives, 121(5), 521-530.

[30] Green, T. R. (2016). Linking Climate Change and Groundwater. Integrated Groundwater Management, 97-141.

[31] Opiyo-Akech et al., 2002. "Human impact on groundwater quality along the Kenyan coast: A case study on an unconfined aquifer to the north of the coastal town of Malindi, Kilifi District Kenya. In: R.S. Arthurton. H.H. Kremer, E. Odada, W. Salomons and J.I. Marshall Crossland (eds.)". In: LOICZ Reports and Studies No. 25 pp. 181-193. University of Nairobi; 2002.

[32] Saana, S. B. B. M., Fosu, S. A., Sebiawu, G. E., Jackson, N., \& Karikari, T. (2016). Assessment of the quality of groundwater for drinking purposes in the Upper West and Northern regions of Ghana. SpringerPlus, 5(1).

[33] Ochungo et al., 2018. Water Supply Security in a Drought Exposed Nairobi: Adopting a Blockchain Provenance Tracking for Informal Alternatives. IJERA. Vol. 7, Issue 10, October 2018.

[34] Darapu et al., 2018. Determining Water Quality Index for the Evaluation of Water Quality of River Godavari. International Journal of Engineering Research and Applications (IJERA). Vol. 1, Issue 2, pp.174-182.

[35] Khan et al., 2005. Application of CCME Procedures for Deriving Site-Specific Water Quality Guidelines for the CCME Water Quality Index. Water Qual. Res. J. Canada, 2005 • Volume 40, No. 4, 448-456.

[36] Akter, T., Jhohura, F. T., Akter, F., Chowdhury, T. R., Mistry, S. K., Dey, D., ... Rahman, M. (2016). Water Quality Index for measuring drinking water quality in rural Bangladesh: a cross-sectional study. Journal of Health, Population and Nutrition, 35(1).

[37] Lohani, B. N., \& Todino, G. (1984). Water Quality Index for Chao Phraya River. Journal of Environmental Engineering, 110(6), 1163-1176.

[38] Mădălina, Paiu \& Breabăn, Iuliana. (2014). WATER QUALITY INDEX - AN INSTRUMENT FOR WATER RESOURCES MANAGEMENT. 
[39] Bohnert, H. J. (2007). Abiotic Stress. Encyclopedia of Life Sciences.

[40] Icaga Y (2007). Fuzzy evaluation of water quality classification. Ecol. Indic. 7, 710-718.

[41] Ocampo-Duque W, Ferre-Huquet N, Domingo J L, Schuhmacher M. (2006) Assessing water quality in rivers with fuzzy inference systems:a case study. Environ. Int. 32, 733-742.

[42] Silvert W (2000) Fuzzy indices of environmental conditions. Ecol.Model. 130, 111-119.

[43] Thivya et al., 2014. Evaluation of drinking water quality index (DWQI) and its seasonal variations in hard rock aquifers of Madurai district, Tamilnadu. International Journal of Advanced Geosciences, 2 (2) (2014). 48-52.

[44] Brown, R. M. Mc Clelland, N. I. Deininger, R. A. and Tozer, R. G. (1970). “A Water Quality Index Do We Dare” Water Sewage Works, Vol. 117, No. 10, 1970, pp. 339-343.

[45] White C. Handbook of chlorination. NY, NY: Van Nostrand Reinhold Company; 1972.

[46] Horton, R.K., "An index number system for rating water quality", J. Water Pollu. Cont. Fed., 37(3). 300-305. 1965.

[47] Destandau, F. and Pascal Diop, A.P. (2016). An Analysis of the Value of Additional Information Provided by Water Quality Measurement Network. Journal of Water Resource and Protection, 2016, 8, 767-776

[48] Bigoni et al., 2014 Drinking water quality assessment and corrosion mitigation in the hospital water supply system of Chacas Village (Peru). Rev. Ambient. Água vol. 9 n. 3 Taubaté - Jul. / Sep. 2014.

[49] Nazir et al., 2016. Classification of Drinking Water Quality Index and Identification of Significant Factors. Water Resour Manage.

[50] Babaei, F. Semiromi, \& Hassani, Amir \& Torabian, Ali \& Karbassi, A. R. \& F. Lotfi, Hosseinzadeh. (2011). Water quality index development using fuzzy logic: A case study of the Karoon River of Iran. AFRICAN JOURNAL OF BIOTECHNOLOGY. 10. 10125-10133.

[51] Yisa, J., 2010. Analytical studies on Water Quality Index of River Landzu. Am. J. Applied Sci., 7: 453-458.

[52] Harish, N. and Reddy, U.C.B (2016). Analysis of Water Quality Index for Groundwater in Gudur Mandal, SPSR Nellore District - Integrated With RS And GIS. Int. Journal of Engineering Research and Applications. Vol. 6, Issue 5, (Part - 2) May 2016, pp.09-15.

[53] Nasirian, Mohsen. 2007. A New Water Quality Index for Environmental Contamination Contributed by Mineral Processing: A Case Study of Amang (Tin Tailing) Processing Activity. Journal of Applied Sciences, 7: 2977-2987.

[54] Johnson et al. (2016) Microbiological Quality Assessment of Drinking Water in Lalo Commune, Benin (West Africa). Journal of Water Resource and Protection, 8, 816-822.

[55] Canadian Council of Ministers of the Environment, 2001. Canadian Environmental Quality Guidelines for the Protection of Aquatic Life.

[56] Cude, Curtis. (2001). Oregon Water Quality Index: A Tool for Evaluating Water Quality Management Effectiveness. JAWRA Journal of the American Water Resources Association. 37. $125-137$.

[57] UNEP, 2007. Global Drinking Water Quality Index Development and Sensitivity Analysis Report.

https://www.un.org/waterforlifedecade/pdf/global_drinking_water quality_index.pdf.

[58] Hrudey, S. E., Hrudey, E. J., \& Pollard, S. J. T. (2006). Risk management for assuring safe drinking water. Environment International, 32(8), 948-957.

[59] Hrudey, S.E. and Hrudey, E.J. Safe Drinking Water-Lessons from Recent Outbreaks in Affluent Nations. London, UK: IWA Publishing; 2004

[60] Genius, M., and K. P. Tsagarakis (2006). Water shortages and implied water quality: A contingent valuation study, Water Resour. Res., 42, W12407.

[61] Kumpel,E and Nelson, K.L (2014). Mechanisms Affecting Water Quality in an Intermittent Piped Water Supply. Environ. Sci. Technol. 2014, 48, 2766-2775.

[62] Magtibay, B., Anama, M. S., \& Fernando, A. (2015). An assessment of drinking-water quality post-Haiyan. Western Pacific Surveillance and Response Journal, 6 (Suppl 1), 48-52.

[63] Trevett et al., 2005. Mechanisms leading to post-supply water quality deterioration in rural Honduran communities. International
Journal of Hygiene \& Environmental Health, Vol. 208(3), 13 May 2005, pp.153-161

[64] Liang, Tung \& Nnaji, Soronadi. (1983). Managing Water Quality by Mixing Water from Different Sources. Journal of Water Resources Planning and Management-asce - J WATER RESOUR PLAN MAN-ASCE. 109. 10.1061/(ASCE)0733-9496(1983)109: 1(48).

[65] Sinai G, Koch E, Farbman M. 1985. Dilution of brackish water in irrigation networks-an analytic approach, Irrigation Science 6: 191-200.

[66] Dietrich, Andrea. (2015). USEPA Secondary Maximum Contaminant Limits: A Strategy for Drinking Water Quality and Consumer Acceptability.

[67] Grayman, Walter M.(2018). History of water quality modeling in distribution systems. 1st International WDSA / CCWI 2018 Joint Conference, Kingston, Ontario, Canada - July 23-25, 2018.

[68] Alfonso S. J. L. (2006). Use of hydroinformatics technologies for real time water quality management and operation of distribution networks. Case study of Villavicencio, Colombia. Thesis at UNESCO-IHE Institute for Water Education, Delft, the Netherlands.

[69] Iqbal, M. M., Shoaib, M., Farid, H. U., \& Lee, J. L. (2018). Assessment of Water Quality Profile Using Numerical Modeling Approach in Major Climate Classes of Asia. International Journal of Environmental Research and Public Health, 15(10), 2258.

[70] Ketata, M., Gueddari, M., Bouhlila, R., 2011. Use of geographical information system and water quality index to assess groundwater quality in El Khairat deep aquifer (Enfidha, Central East Tunisia). Arabian Journal of Geosciences, 1-12.

[71] Khan, A. A., Paterson, R. \& Khan, H. Modification and Application of the CCME WQI for the Communication of Drinking Water Quality Data in Newfoundland and Labrador. In: 38th Central Symposium on Water Quality Research, Canadian Association on Water Quality, Burlington, Canada (2003).

[72] Backman, B., Bodiš, D., Lahermo, P., Rapant, S., \& Tarvainen, T. (1998). Application of a groundwater contamination index in Finland and Slovakia. Environmental Geology, 36(1-2), 55-64.

[73] Tiwari, T.N., Mishra, M., 1985. A preliminary assignment of water quality index to major Indian rivers. Indian Journal of Environmental Protection 5 (4), $276 \mathrm{e} 279$.

[74] Dissmeyer, G.E. (2000). Drinking Water from Forests and Grasslands .A Synthesis of the Scientific Literature. United States Department of Agriculture. Forest Service. Southern Research Station General Technical Report SRS-39.

[75] Abbasi, S.A., 2002. Water Quality Indices. State of the art report, Scientific Contribution No.-INCOH/SAR-25/2002. INCOH, National Institute of Hydrology, Roorkee.

[76] Abbasi, T., \& Abbasi, S. A. (2012). Water-Quality Indices of USA and Canada. Water Quality Indices, 175-186.

[77] Kereyu, D.D. (2013). A GIS based water quality management - a case study of water supply for the city of Nairobi .Masters degree thesis at the Department of Civil and Construction Engineering of the University of Nairobi.

[78] Chepyegon, C. and Kamiya, D. (2018) Challenges Faced by the Kenya Water Sector Management in Improving Water Supply Coverage. Journal of Water Resource and Protection, 10, 85-105.

[79] Muraguri, P.M. (2013). Assessment of Groundwater Quality in Nairobi County, Kenya. Thesis, Jomo Kenyatta University of Agriculture and Technology.

[80] Osoro, Veronica (2015). A survey of disinfection by-products in tap water from selected areas in Nairobicounty and Thika sub-county, Kenya. Masters degree Thesis- Jomo Kenyatta Univerity of Agriculture and Technology.

[81] Cutler, David \& Miller, Grant. (2005). The Role of Public Health Improvements in Health Advances: The Twentieth-Century United States. Demography. 42. 1-22.

[82] Dinius, S. H. (1972). Social accounting system for evaluating water resources. Water Resources Research, 8(5), 1159-1177.

[83] Walski, T. M., \& Parker, F. L. (1974). Consumers water quality index. Journal of the Environmental Engineering Division, 100, 259-611.

[84] Deininger, R. \& Landwehr., J. M. A water quality index for public water supplies. School of Public Health, Univ. of Michigan, Ann Arbor (1971)

[85] Bartram, J. and Ballance, R. [Eds] 1996 Water Quality Monitoring: A Practical Guide to the Design and Implementation of Freshwater Quality Studies and Monitoring Programmes. Chapman and Hall, London. 
[86] Abassi, S.A., 1999. Water Quality Indices, State-of-the art. J.IPHE, No.1.

[87] Lo, A.W. (2016). 'What is an index?', Journal of Portfolio Management, Vol. 42, No. 2, pp.21-36.

[88] Smith, D. G. (1987). Water quality indexes for use in New Zealand's rivers and streams. Water Quality Centre Publication No. 12, Water Quality Centre, Ministry of Works and Development, Hamilton, New Zealand (1987).

[89] Meybeck, M. and Helmer, R. 1989 The quality of rivers: from pristine state to global pollution. Paleogeog. Paleoclimat. Paleoecol. (Global Planet. Change Sect.), 75, 283-309.

[90] Liebmann,H.(1969). Atlas of Water Quality, Methodic and practical conditions. R. Oldenbourg Verlag 1969. International Review of Total Hydrobiology and Hydrography, 54 (5), 804-804.

[91] Prati, L., Pavanello, R., \& Pesarin, F. (1971). Assessment of surface water quality by a single index of pollution. Water Research, 5(9), 741-751.

[92] Harkins, D. R. (1974). An objective water quality index. Journal - Water Pollution Control Federation. 46. 588-91.

[93] Sargaonkar, A. \&, Deshpande, V. Development of an overall index of pollution for surface water based on a general classification scheme in Indian context. Environmental Monitoring and Assessment, 89, 43-67 (2003).

[94] Stoner, J. D. Water quality indices for specific water use. U.S. Geological Survey, Reston, Y.A. Circular, 140-770 (1978).

[95] Nemerow, N. L., Sumitomo, H. Benefits of water quality enhancement. Syracuse, University, Syracuse, N.Y., Report No. 16110 DAJ (1970)

[96] Landwehr, J. M. (1979). A statistical view of a class of water quality indices. Water Resources Research, 15(2), 460-468.

[97] Dee, N., Baker, J., Drobny, N., Duke, K. M., Whitman, I. \& Fahringer, D. An environmental evaluation system for water resource planning. Water Resources Research, 9(3), 523-535 (1973)

[98] Mc Duffie, B. \& Haney, J. T. A proposed river pollution index. American Chemical Society, Division of Water, Air and Waste Chemistry, New York, NY (1973)

[99] Bharti, N. \& Katyal, D. Water quality indices used for surface water vulnerability assessment. International Journal of Environmental Sciences, 2(1): 154-173 (2011).

[100] Saeedi, M., Abessi, O., Sharifi, F., \& Meraji, H. (2009). Development of groundwater quality index. Environmental Monitoring and Assessment, 163(1-4), 327-335.

[101] Gorde, S. P. and Jadhav, M. V. (2013). Assessment of Water Quality Parameters: A Review Int. Journal of Engineering Research and Applications.

[102] Soltan, M. E. (1999). Evaluation of groundwater quality in Dakhla Oasis (Egyptian Western Desert). Environmental Monitoring and Assessment, 57(2), 157-168.

[103] Olasoji et al., 2019.Water Quality Assessment of Surface and Groundwater Sources Using a Water Quality Index Method: A Case Study of a Peri-Urban Town in Southwest, Nigeria. Environments. 2019, 6(2), 23.

[104] Ehya F, Marbouti Z (2018) Groundwater quality assessment and its suitability for agricultural purposes in the Behbahan Plain, SW Iran. Water Pract Technol.

[105] Annapoorna, H., \& Janardhana, M. R. (2015). Assessment of Groundwater Quality for Drinking Purpose in Rural Areas Surrounding a Defunct Copper Mine. Aquatic Procedia, 4, 685-692.

[106] Subramani, T., Elango, L., \& Damodarasamy, S. R. (2005). Groundwater quality and its suitability for drinking and agricultural use in Chithar River Basin, Tamil Nadu, India. Environmental Geology, 47(8), 1099-1110.

[107] Nagarajan, R., Rajmohan, N., Mahendran, U., \& Senthamilkumar S. (2010). Evaluation of groundwater quality and its suitability for drinking and agricultural use in Thanjavur city, Tamil Nadu, India. Environmental Monitoring and Assessment, 171(1-4), 289-308.

[108] Alaya, M. B., Saidi, S., Zemni, T., \& Zargouni, F. (2013) Suitability assessment of deep groundwater for drinking and irrigation use in the Djeffara aquifers (Northern Gabes, southeastern Tunisia). Environmental Earth Sciences, 71(8), 3387-3421.

[109] Warda et al., 2018. The suitability of géothermal waters for irrigation, Oued Righ area, South-easthern Algeria. Journal of Biodiversity and Environmental Sciences (JBES). Vol. 13, No. 4, p. 211-224, 2018.

[110] Bouderbala, A. (2015). Assessment of Groundwater Quality and its Suitability for Agricultural Uses in the Nador Plain, North of Algeria. Water Quality, Exposure and Health, 7(4), 445-457.

[111] Soroush, M., Ehya, F., \& Maleki, S. (2016). Major and trace elements in some bottled water brands from Khuzestan Province market, SW Iran, and accordance with national and international standards. Environmental Earth Sciences, 75(4).

[112] Amir, Ali \& , Khan \& Tobin, Annette \& Paterson, Renée \& Khan, Haseen \& Warren, Richard. (2005). Application of CCME Procedures for Deriving Site-Specific Water Quality Guidelines for the CCME Water Quality Index. Water Quality Research Journal of Canada. 40.

[113] Beguy, D., Elung’ata, P., Mberu, B., Oduor, C., Wamukoya, M., Nganyi, B., \& Ezeh, A. (2015). Health \& Demographic Surveillance System Profile: The Nairobi Urban Health and Demographic Surveillance System (NUHDSS). International Journal of Epidemiology, 44(2), 462-471.

[114] Owuor,S.O and Mbatia,T.(2008). Post independence development of Nairobi city, Kenya. Paper presented at Workshop on African capital Cities Dakar, 22-23 September 2008.

[115] Morgan, W.T.W. (ed.) (1967), Nairobi city and region. Nairobi: Oxford University Press

[116] Gutkind, P. C. W. (1968). Nairobi: City and Region. Edited by W. T. W. Morgan. Nairobi: Oxford University Press, 1967. Pp. ix, 154, ill., map. 42s. 6d. Africa, 38(03), 353-354.

[117] Central Bureau of Statistics (2009). Population and Housing Statistics. Population Projections by Province. Nairobi Central Bureau of Statistics. Retrieved from www.cbs.go.ke.

[118] UN-HABITAT. The State of African Cities 2008 - A Framework for Addressing Urban Challenges in Africa. Nairobi: UNHABITAT, 2008.

[119] Onyancha, C. and Getenga, Z. (2013).Geochemistry of Groundwater in the Volcanic Rocks of Nairobi City. Global Journal of Science Frontier Research Environment \& Earth Science Volume 13 Issue 3 Version 1.0 Year 2013.

[120] Ledant, Martin 2013. Water in Nairobi: Unveiling inequalities and its causes », Les Cahiers d'Outre-Mer, 263 | 2013, 335-348.

[121] Eckart, J., K. Ghebremichael, K. Khatri, S. Tsegaye, and K. Vairavamoorthy. 2012.“Integrated Urban Water Management for Nairobi.” Report prepared for theWorld Bank by Patel School of Global Sustainability, University of SouthFlorida, Tampa. (Available upon request from the authors, World Bank.).

[122] Coetsiers et al., (2008). Hydrochemistry and source of high fluoride in groundwater of the Nairobi area, Kenya. Hydrological Sciences-Journal-des Sciences Hydrologiques, 53(6) December 2008.

[123] Shah, K. A., \& Joshi, G. S. (2015). Evaluation of water quality index for River Sabarmati, Gujarat, India. Applied Water Science, 7(3), 1349-1358. 